\title{
Implementing Teaching Factory Learning to Increase Students' Achievement in Fashion Business Management Subject
}

\author{
Sicilia Sawitri \\ ${ }^{I}$ Engineering Faculty, Universitas Negeri Semarang, Sekaran Gunungpati, Semarang, Indonesia. \\ sicilia.sawitri@mail.unnes.ac.id
}

Keywords: Teaching Factory Learning, Students achievement, Fashion Business Management Subject.

\begin{abstract}
The graduate students of Fashion Education Study Program at Home Economic Department must have selfconfidence to manage their own businesses. In the curriculum of study program, there are some subject, one is The Fashion Business Management subject has 3-semester credit system it is not enough to create their own business. The instructional methods used in delivering the instructional material were lecture method and assignment method not maximized. Many instructional strategies are offered by the lecturer. On this paper the strategy which will be applied was teaching factory learning. Actually this method gives to vocational senior high school. The aims of this research: to know the students' achievement in Fashion Business Management subject by implementing teaching factory learning. The experiment method one shot case study was used in this research. The samples were 24 students who attended the Fashion Business Management subject. The data was collected by using achievement test. By using descriptive percentage the data was analyze. The result was, the students' achievement were in good criterion, $83.41 \%$. The suggestions were: The implementation teaching factory learning need a special place for students to manage the business and need support from the Home Economics Department
\end{abstract}

\section{INTRODUCTION}

The revolution Industry 4.0 is one of the advantages of development technology. Many industries rose rapidly, such as fashion industries. The high industries need for skilled worker (Damarjati, 2017). To take advantage of these high techologies, the industry required quality human resourches (Lamancusa et.al chitted by Putra et al 2o17). It need education which give the students some skill in the work field. One of the education which prepare the students to become ready in the work field is Fashion Education Study Program.

Fashion Education Study Program produce graduate who can work in vocational school as a teacher or educator, entrepreneur in fashion by opening business. The students as a teacher who teaching at vocational senior high school, they have to know how to give some experience in managing business. In addition to their profession as a teacher does not close to the possibility for graduates to become entrepreneur in fashion. Some of the fashion businesses that can be applied by the graduates are: dress making, tailor, haute couture (high fashion) fashion shop, management of fashion course, chain store. To become a fashion entrepreneur in fashion it takes variety of skills, but the main is the source from themselves such as interest, creativity and ability to manage the fashion business. There are some various subject provide for the students of Fashion Education study program, are:(1) Fashion Design group (Basic Fashion Design, Continuous Fashion Design, Advance Fashion Design, Fashion Decoration, Textile Design, Fashion Show Management), (2) Clothing: Children Ware, Men Ware, Women Ware, Tailoring Management, Haute Couture Management, Indonesian Fashion, lingerie, (3) Supporting group: Textile Science, Textile Craft, Fashion Accessories, Fashion Business Management, Entrepreneurship,

One of those subjects which gives the experience in managing fashion business is Fashion Business Management Subject. This subject has 3 credit semester system, that contain of the basic concepts 
- Conducting research and devotion in the field of fashion conservation. enterprise in fashion and manage fashion business. The management provides include: management of production and service, business finance, marketing, human recourses. In addition it require students to practice to manage real fashion business. The students open the dress making enterprise. As a candidate teacher in vocational senior high school and entrepreneur, the students should have the ability to manage the fashion business in accordance with the type of fashion business. This ability can be later transferred to the students and can be uses as a side job as vocational teacher or fashion business owner who manages independently.

Therefore it is necessary to find a solution that can be accommodate students learn to manage the fashion business more creative and innovative. It needs a model of learning which can accomoodate the students to practice the busines like in an fashion industry. One of some instructional model were suitable to the that condition is teaching factory learning.

Teaching factory learning was desinged for vocational senior high school, is industry-based learning concept include product and service, through synergy between school and is industry partners to produce competent graduates (Damarjati, 2017). The Teaching Factory concep has gained major interest, especially in the US, resulting in a number of educational and /or business pilot activities.

The aims of this research: to know the students' achievement in Fashion Business Management subject by implementing taching factory learning.

\section{FASHION EDUCATION STUDY PROGRAM}

Fashion Education study program is one of the program in Home Economics Department, has a vision: Educational Institution to prepare the graduated have professional education, mastering technologyy in fashion field and oriented conservation in international standard, healthy, superior and prosperous in the year 2020 (Pendidikan Tata Busana, 2015).

The study program mission as follow:

- Organizing a high education in the field of fashion in international standard and conservation.

- Organizing vocational education in the field of fashion based conservation
- Implement noble value, science, technology, art and culture base on conservation in the community.

The mission can be realized through the objective of the study program, described as follow:

- Produce academic and vocational personnel who have superior competence in the fashion.

- Developing innovative lecturer models that are relevant to the needs of stakeholder.

- Improving the quality of education, educational research, and community service in fashion field.

- Implement and disseminate the result of research and community servise in fashion field based on conservation.

The goal can be achieve through the provision of course by preparing many subjects which supports the competence to be achieved. The subjects which should selected by student such as: Fashion Design, Textile, Children Ware Management, Men Ware Management, Tailoring Management, Fahion Business Management.

\subsection{Fashion Business Management Subject}

One of the subject in Fashion Education Study Program is Fashion Business Management. This subject consists of 3 semester credit system. The material in this subject are: 1. Make a plan how to do the business, 2. Doing the business and 3 . Evaluate the business.

The standard competencies of Fahion Business Management subject are' preparing the students' knowledge, skill and motivation to realize their idea to become a successful vocational teacher, fashion designer, and entrepreneur.

The success of learning Fashion Business Management subject, is influenced by several factors, for example: learning materials, insructional media, instructional model, learning method, classroom management, evaluation system, teachers and the students themself.

Industrial oriented learning requires a learing model appropriate to the competencies. Therefore, in the course of Fashion Business Management, s necessary to choose a learning model which can increase students' creativity, ability to manage the fashion business. One of the model was Teaching Factory Learning. 


\subsection{Fashion Business Type}

Some advantages of science and technology have impacted a lot of people's lives, no exception in the field of dressmaking industry. The discovery of industrial machines by experts and abundance of raw materials of textile have inspired many people to start a fashion business. Fashion business according to Rulanti Satyodirgo as cited by Sri Wening and Sawitri (1994) mentioned several kinds of businesses, namely: sewing course, business couturier, tailor, haute couture, boutique, small scope garment, large scope garment factories, and intermediate fashion business.

Sewing Course/instead of producing cloths it produces skilled personnel and indirectly represents the fashion business. There are several types of sewing courses and the levels of student ability after completing the course. While the grade levels in the course can be divided into: 1) basic level, 2) skilled level, 3) advanced level, and 4) sewing teaching level.

Couturier business is one of types in the field of fashion businesses for individuals, in this case the customer comes and is measured to fit the appropriate size and then the clothes are produced. Sri Wening and Savitri (1994:95) defined couturier (dress maker) as the individual fashion business type by measuring each customer particularly for women and children. At first it is only a side-job for housewives to spend their spare times as well as to earn some additional income for family. All jobs starting from measuring, creating patterns, and cutting to the final product they perform by themselves. They, generally, use simple equipment. The system used in the couturier business is semi tailoring, i.e. a fashion finishing technique with merely veering process. Service products usually made are women and children clothing.

Tailor business is a service business which receives orders with tailoring systems, typically working on menswear. Tailoring system is a sewing technique in which either the outside and inside of the cloth produces is neatly covered with upholstery fabric (lining). Fashion models in tailor business are generally coats or semi-coats.

Haute couture comes from the French language (Yerusalem, 2011: 17) which means high cutout. Haute couture business is an exclusive fashion business, both in terms of design and materials and finishing techniques. A unique design is intended merely for one customer with good quality and exclusive material given as well as finishing technique needs a special attention; thus the price of a fashion produced in hatue couture is certainly expensive. Haute couture is a reserved term and only used on the standards set by the ChambreSyndicale de la Couture. . A couture garment is made to order for an individual costumer, and is usually made from high-quality, expensive fabric, sewn with extreme attention to detail and finish, often using time-consuming, hand-executed techniques. The famous Indonesia haute couture designers are: Harry Dharsono, Piter Sie, Adji Notonegoro, Iwasn Tirta. They are really successful entrepreneur.

Boutique is a fashion business that sells clothes and accessories (Dunn, 1974). The quality of these clothes is usually good, smooth and neat stitching, and limited production number. Accessories that are available in the boutique include an assortment of jewelry, shoes, sandals, handbags, scarves, belts and many others. At the boutique businesses, they do not receive sewing orders; the stocks are supplied by other companies that produce clothes and accessories. Type of clothing sold in the boutique is ready-to-wear fashion.

Mass Production Clothing Business provides customers with large quantities and produces readymade clothing in large quantities and use standard sizes (S, M, L, XL, LLL etc.). The materials that are generally used are less expensive materials, thus the price can be affordable by the lower classes. The selected trends are generally adapted from the clothing worn by famous people. The use of materials with low price and simple techniques with a machine enable to produce cheap-priced clothes. Mass production conducted in the industry is generally called garment, while production conducted in houses is called convection.

Fashion courier business is a business conducted by individuals that become a courier to collect or provide storage places for home-made clothes products and then they sell or find the market in order to get some profits (Wening, Sawitri, 1994)

\subsection{Teaching Factory Learning in, Fashion Business Management Subject}

Teaching Factory learning is an instructional model in vocational education which use product as instructional media to deliver the competition and conduct in the school and industry (Direktorat Pembinaan SMK Kemendikbud, 2017).

Teaching factory learning as instructional model effective and efficient. Effective, it mean teaching factory can prepare the students reach the competenc 
- Sumbit or dilivery the order to the customer.

efficient, mean the insturcional used this model is operational, need low cost, easy to be implemented (Direktorat Pembinaan SMK, 2017). Teaching factory learning concep has gained major interes, especially The component in teaching factory learning are: product, job sheet and schedule (Direktorat Pembinaan SMK, 2017). The concept of Teaching Factory Learning is based on the knwoledge triangle notion, aiming to become a new paradigm for both academic and industrial learning. (Rentzos et al, 2015)

The principles of teaching factory learning, are: efficient, effective, integrated and collaboration. Increasing the efficiently in using equipment and material. Increasing efficiently using tool and material. Create learning situation match to real condition in industry in order to achieving completely. Integrated subject, collaboration to the enterprise.

The basic value in teaching factory learning, are: Sense of Quality, sense of efficiency, sense of creativity and innovation.

Teaching factory learning was created for vocational senior high school, but it can be applied in higher education, as Fashion Education Study Program. The model used TF6M Model (Martawijaya, 2012), consist: (1) Receive order, (2) Analyze order, (3) Execute order, (4) Doing the order, (5) Quality Control, (6) Submit the order

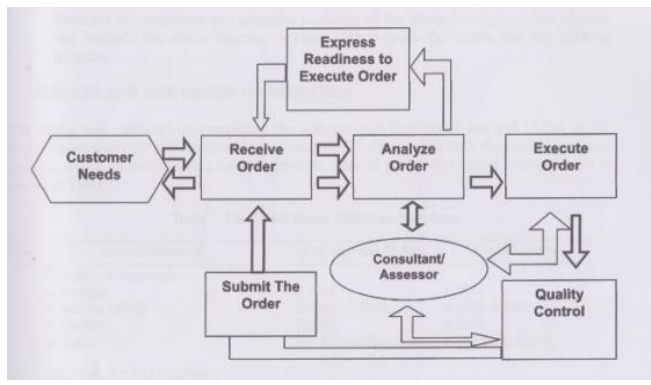

Figure 1. The Scheme of TF6M Model

Implementing TF6M in Fashion Business Management: after the students discuss with customer, the step were:

- Receive the order, it can be childern wear, men wear or women wear. They discuss about the fashion design

- Analyze the order,

- Excute the order, students were ready to make the product as discuss.

- Doing the order, start pattern making, cutting sewing, fitting, finishing.

- Quality Control, check and recheck the products.

\section{RESEARCH METHOD}

The type of research used in this study is an experiment by applying teaching factory learning on the Fashion Business Management subject in Fashion Education Study Program. The research design for experimental research method was Oneshot case study, to know the students' achievement of Fashion Business Management subject.

$$
\mathrm{X} \quad \mathrm{O}_{1}
$$

The instrument used in this research were observation sheet on business management capability, business activity observation sheet, with assessment indicator: (1) Proposal Preparation, (2) Proposal Preparation, (3) Students activity in conducting the fashion business. Data analysis technique was done by using descriptive percentage.

\section{RESULT AND DISCUSSION}

By using descriptive percentage analysis, the result, the students' achievement in Fashion Business Management Subyect was $83.41 \%$, it was high catagory.

Based ont the result of descriptive analysis, it can be seen, the students' achievement in Fashion Business Management subject was high. That may cause, the students who joint to Fashion Business management are indeed good, and have interested in fashion business, since they know if they can manage the fashion business, they can create new enterprise and recruit the people who live around.

The increasing of student achievement began when they started receive the order. The students can discuss to the customer about the order. They can give advice to the costumer the good fashion, based on their knoledge which they got from the lecturer. In the past, students got entrepreneur subject and can be applied when they do the fashion business.

The step analyzes the order, in this time student can used all of fashion knowledge and skill, which they got on Fashion Design subject, the quality of the fashion they knew from Textile Analyze subject. For example, the customers asked the student to draw a fashion design for them. The students with her fashion competency, created the fashion design 
The success of students in optaining in score on and discussed to the customers, after the customers agreed, the students started to made patterns, bought the fabric and accessories, and then sewed and finished the dress or blazer or blouse, etc.

The students can real practice such in small industry (dress making) when they conducted real fashion business in their boarding house. They create their boarding house as a new enterprise

The students had self-confidence when the customers were satisfied got the product, in good result and packing. The students had freedom to manage the fashion business.

After the project finished, the students practiced the fashion business, they had self-confidence to open a new fashion business by accepting orders from customers, and they have motivation in doing the business. According Martawijaya (2012) TF-M6 model also useful to improve the students' motivation, sense of responsibility as well as work ethics.

The Teaching Factory Learning is not the only model that influence students learning outcome in Fashion Business Management subject, it could be the subject matter before Fashion Business Management, such as Entrepreneurship, Women Wear Management, Men Wear Management, Fashion Design, and many fashion businesses around the students.

The existence of student learning outcome inf Fashion Business Management Subject was 83.41 $\%$, including in high category. It meant the teaching factory learning influence students' achievement in Fashion Business Management Subject. The learning process gave experience to the students in managing the fashion business, it also gave the readiness to the students, to manage it. According Dewi and Sudira (2018), implementation of teaching factory program of vocational high schools, it can increase the work readiness.

The learning process of Fashion Business Management syvhect which is a couurse that several time conducted. In the previous year, a project-based learning model had been developed, whis was thought to be able to improve students' learning outcome. Another way to conduct the course, by implementing Teaching Factory Learning model, students are giben the freedom to look for problems related to fashion business in work place, in groups, for examples: reviewing fashion thaat is popular in community, that can be use as a source of inspiration to make new products. The results of the students analysis, they got positive impact, because students would find the development of more varied ne design. the course in Fahion Business Management was caused of the Teaching Factory learning model, emphasizing the activity, creativity and cohesiveness of students when carrying out independents Fashion Business Management. This provides an opportunity for students to find ways to arrange a fashion business based on finding in the market analysis.

The limited of research, were: (1) There were no special classroom to do the Teaching Factory learning in Fahion Business Management Subject. The students' achievement in Fashion Business Management could be increase, if the class had complete facilities and infrastructure for fashion business. The students did the fashion business at their boarding house. (2) The Fashion Business Management, given to 5th semester, the students felt do not have skill in managing the business,. The students' ability in sewing were still limited. because the studentts did not have skill in Tailoring Management, High Fashion Management. The could not make a product in tailoring or high fashion technique. (3) The process of Fashion Business Management Subject without collaboration with small fashion enterprise in Semarang, such as: dress making, tailoring,

\section{CONCLUSIONS}

The achievement of the students on Fashion Business Management subject was 83.41, it was gook category. It can be increase more than in the pass, if the lecturer always give support to the students to manage the fashion business.

Based on the result, teaching factory learning can be applied in another subject, such as Children wear management, Garment Management, Tailoring Management, High Fashion Management, Men wear management, Women wear management

The implementation teaching factory learning need a special place for students to manage the business and need support from the Home Economics Department, and Engineering Faculty. Need cooperation with fashion enterprise surround Semarang State University

\section{REFERENCES}


Damarjati, T. (2017). Teaching Factory in Indonesia, Directorate of Technical and Vocational Education. Jakarta: Ministry of Education and Culture.

Dewi, S.S and Sudira, P, (2018). The Contribution of Teaching Factory Program Implementation on Work Readiness of Vocatonal High School Students in Makasar. Journal of Educational Science and Technology, 4(2), 126-131.

Direktorat Pembinaan SMK, Kemdikbud. (2017), Panduan Teknis Teaching Factory, Jakarta: Lembaga Pendidikan dan Pelatihan Kejuruan SED TVET, Pusdiklat Industri, Kemenperin, Direktorat Pembinaan SMK, Kemdikbud.

Direktorat Pembinaan SMK. (2017). Tata Kelola Teaching Factory, Jakarta: Direktorat Pembinaan Sekolah Menegah Kejuruan, Kemendikbud

Dunn, GM. 1974. Fashion Design, Sydney, Melbourne, Brisbane, Perth: Rigby Limited.

Fashion Education Study Program. (2015). Kurikulum Pendidikan Tata Busana. Semarang: Jurusan PKK, Program Studi Tata Busana. UNNES

Jerusalem, M.A, (2011). Manajemen Usaha Busana, Yogyakarta: Fakultas Teknik UNY

Martawijaya, D H, (2012), Developing a Teaching Factory Learning Model to improve Production Competencies Among Mechanical Engineering Students in A Vocational Senior High School. Journal of Technical Education and Training, 4(2), 45-56.

Pendidikan Tata Busana. (2015). Kurikulum Pendidikan Tata Busana, Semarang: Jurusan PKK Fakultas Teknik Unnes.

Putra, R.C. et al, 2017. Design Learning of Teaching Factory in Mechanical Engineering. IOP Publishing, $1-5$

Rentzos, L., Mavrikios, D., Chryussolouris, G. (2015), A Two-way Knowledge Interaction in Manufacturing Eduction: The Teaching Factory. Procedia CIRP, 32, 31-35.

Wening, S and Sawitri, S. (1994). Dasar-dasar Pengelolaan Usaha Busana, Bahan Ajar. Yogyakarta: IKIP Yogyakarta

Yunanto, D. (2016). Implementasi Teaching Factory di SMKN 2 Gedangsari Gunungkidul. Jurnal Vidya Karya, 31(1). 